« Še'r-e Ḥâfez dar zamān-e Ādam andar bāè-e Hold.

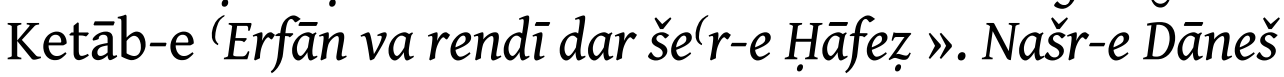
, 20, 1 (1382/2003), pp. 37-41.

\title{
Charles-Henri de Fouchécour
}

\section{(2) OpenEdition \\ 1 Journals}

Édition électronique

URL : http://journals.openedition.org/abstractairanica/1914

ISSN : 1961-960X

\section{Éditeur :}

CNRS (UMR 7528 Mondes iraniens et indiens), Éditions de l'IFRI

\section{Édition imprimée}

Date de publication : 15 mai 2005

ISSN : 0240-8910

\section{Référence électronique}

Charles-Henri de Fouchécour, « « Šerr-e Hāezez dar zamān-e Ādam andar bāǵ-e hold. Ketāb-e (Erfān va rendī dar šelr-e Hāâfez ». Našr-e Dāneš, 20, 1 (1382/2003), pp. 37-41. », Abstracta Iranica [En ligne],

Volume 26 | 2005, document 359, mis en ligne le 07 décembre 2005, consulté le 25 septembre 2020. URL : http://journals.openedition.org/abstractairanica/1914

Ce document a été généré automatiquement le 25 septembre 2020.

Tous droits réservés 


\title{
« Še'r-e Ḥāfez dar zamān-e Ādam andar bā $\dot{g}$-e Hold. Ketāb-e (Erfān va rendī dar še'r-e Hāâfez. ». Našr-e Dāneš, 20, 1 (1382/2003), pp. 37-41.
}

\author{
Charles-Henri de Fouchécour
}

Un grand article sur un grand livre, celui de Dāryūš Āšūrī, (Erfān va rendī dar šér-e Ḥāfez (Tehrān, Našr-e Markaz, 1379/2000). La description minutieuse du contenu que fait l'A. de l'article permet de situer l'étude dans la continuité du précédent livre de D. Āšūrī, Hasti-šsenāsi-ye Hāâfez ('The Ontology of Hāfiz', Našr-e Markaz, 1377/1998, 305 p.), qui fut, on s'en souvient, apprécié et contesté de plusieurs côtés. Car D. Āšūrī y fondait son analyse de l'ontologie hâfézienne sur la notion d'archétype (sar-nomūn), telle que Mircéa Eliade l'utilisa dans ses travaux d'historien des religions. On le sait, Ḥāfez est tributaire, dans sa conception fondamentale sur l'origine de l'humanité avant le Temps, de ce qu'il trouva dans l'ouvrage de Najm al-Dīn Rāzī Dāye (Merșād al-'ebād) et d'abord dans le commentaire du Coran par Meybodī (Kašf al-asrār). Pour D. Āšūrī, Ḥāfez fonda sur l'archétype de l'Homme Parfait sa notion de rend (en gros, l'amant fou). D. Āšūrī recourt ici à la distinction que put établir Nașrollāh Pūrjavādī entre une école soufie khorâsânienne à caractère inspiré et poétique, et une école soufie à caractère plus théorique et métaphysique, Ḥâfeẓ relevant de la première. D. Āšūrī avance alors une distinction historique dans celle-ci, entre un soufisme fondé sur l'amour de Dieu ('erfān$e$ Hodā-(āšeqāne) tel que le vécut Jalāl al-Dīn Rūmī, et un soufisme fondé sur une attitude de total amour fou ('erfān-e rendāne), propre à Sa'dī, mais surtout à Ḥâfeẓ. Selon D. Āšūrī, chez Ḥāfeẓ l'archétype de l'Homme Parfait se trouve inscrit dans le mythe (osțūre) de sa création dans la prééternité, où il fut chargé du dépôt de l'amour divin. Il y eut un drame dans le ciel de la prééternité, qui lia à jamais l'amant à son Compagnon (yār), l'ange étant exclu de ce privilège qui lança l'homme dans l'aventure terrestre. En somme, D. Āšūrī s'est engagé dans l'analyse du Dìvān de Ḥāfez en philosophe de la littérature persane, "cherchant le mythe ordonnateur de l'ensemble des notions fluentes et parfois contradictoires de la poésie de Ḥāfez », comme l'écrit l'A. de l'article. 
Et non sans prendre beaucoup de risques dans la réduction de sa lecture du monument hâfézien. L'A. souligne que, malgré l'effort exceptionnel de compréhension du Divān, l'entreprise élude des aspects essentiels de la pensée hâfézienne, comme, la marque sur celle-ci de la conception ash'arite du destin. Par ailleurs, D. Āšūrī se hasarde à des expressions lourdes de signification, qui ne conviennent pas à son analyse, comme celle de wah̆dat al-wujūd, ou même celle de l'Homme Parfait telle que Nasafí l'avait conçue. Pour l'A., D. Āšūrī se présente en herméneute au sens moderne de celui qui cherche à reconduire à son principe (be avval bordan) la pensée générative de l'œuvre de Ḥăfez. Initiateur audacieux, D. Āšūrī a suffisamment avancé sa recherche pour enrichir notre vocabulaire sur les points abordés.

INDEX

Thèmes : 11.1.1. Littérature persane classique

nompropre Hāfez, Mircéa Eliade

\section{AUTEURS}

CHARLES-HENRI DE FOUCHÉCOUR

Fondateur de la revue Abstracta Iranica - Paris 